\author{
Anna Szeteli \\ Mónika Dóla \\ Gábor Alberti ${ }^{1}$
}

\title{
Pragmasemantic Analysis of the Hungarian Inferential - Evidential Expression szerint
}

\begin{abstract}
The Hungarian inferential-evidential expression szerint 'according to somebody/something' is highly multifaceted. It can be furnished with person and number suffixes. It can occur in all major sentence types but with different person features and/or collocations. It can be associated with a quotative meaning and can express some kind of judgment in declarative sentences and questions, too. Imperative sentences can serve as a source of its further uses: it can be interpreted both as advice and as an expression of the speaker's firm stance typically based on moral concerns. We intend to account for this extremely complex distribution with respect to person, attitude, sentence type and collocation in a highly systematic and explanatorily adequate manner in the "cognitively viable" representationalist dynamic discourse- and mind-representation theory $\Re$ ReALIS. We attempt to carry out this task in a way that sheds new light on how such expressions make language a basic means of achieving epistemic control and intersubjective alignment.
\end{abstract}

Keywords

inferentiality, evidentiality, uncertainty, quotation, advice, instruction, dynamic pragmasemantics, information state

\section{Introduction}

This paper investigates the pragmasemantic role of the epistemic-evidential postpositional expression szerint in Hungarian grammar (Kugler 2012; Dér 2016). The expression is highly similar to epistemic discourse markers such as

\footnotetext{
${ }^{1}$ G. Alberti is sponsored by NKFIH 120073 (Comprehensive Grammar Resources - Hungarian: Open Access).
} 
valószinüleg 'probably', talán 'perhaps', esetleg 'could possibly': the propositions modified by them should be interpreted as hypotheses.

(1) a. Ili (én)szerintem hazaköltözött.

Ili (I)-EvID-1SG home.move-PAST ${ }^{2}$

'In my opinion, Ili moved back home.'

b. Ili valószínűleg/ talán/ esetleg hazaköltözött.

Ili probably perhaps possibly home.move-PAST

'Ili probably/perhaps/possibly moved back home.'

The difference lies exactly with the pronominal component present in (én)szerintem. This makes the degree of (un)certainty less precise than in the case of the discourse markers given in (1b), ${ }^{3}$ but shows the person who should be regarded as (i) having some evidence e in support of the proposition p, and (ii) having a general, typically underspecified everyday inferential rule which can be specified in the given context as follows: $\mathrm{e} \rightarrow \mathrm{p}{ }^{4}$

It is a further specialty of the paradigm of szerint-expressions that this inferential-evidential discourse marker (Willett 1988: 57), in contrast to other discourse markers (2a), can perform the same information-structural functions as subcategorized arguments in Hungarian (É. Kiss 2002); for instance, the function of an also-quantifier or an only-focus (2b). This property can obviously be traced back to the pronominal basis of szerint-expressions.

(2) a. *Ili [esetleg is hazaköltözött] $/$ [csak esetleg költözött haza]. Ili could.possibly also home.move-PAST only could.possibly move-PAST home

b. Ili [(én)szerintem is hazaköltözött]/ [csak (te)szerinted költözött haza]. Ili (I)-EvID-1SG also home.move-PAST only (you)-EvID-2SG move-PAST home '[In my opinion, too,] / [It is only in your opinion that] Ili moved back home.'

Furthermore, based on the referent who should be regarded as holding the information, szerint can express quotative "hearsay" evidence (3a) as well as judgment (3b) and advice/moral stance (3c).

(3) a. Ili Péter/az újság szerint hazaköltözött.

Ili Péter/the newspaper Evid home.move-PAsT

'Péter/the newspaper says that Ili moved back home.'

${ }^{2}$ Abbreviations are as follows. A - authority; B - belief; D - desire / interest; E - experience; EVID - evidential; i - I (first person); I - intention; INS - instrumental case; o - other (third) person; PL - plural; ReALIS - REciprocal and Lifelong Interpretation System (Alberti and Kleiber 2014); SBJV: subjunctive mode; SG - singular; u - you (second person).

${ }^{3}$ In order to make the degree of certainty more precise, the probability markers in (1b) can be combined with the szerint-expression.

${ }^{4}$ Szerint-expressions express probability indirectly. The inferential rule $\mathrm{e} \rightarrow \mathrm{p}$ is meant as follows: it is not sure, only more or less probable, that $\mathrm{p}$ comes with the evidence $\mathrm{e}$. 
b. Ili (én)szerintem szép.

Ili (I)-EVID-1sg pretty.

'I judge Ili to be pretty.'

c. (Én)szerintem házasodjatok össze!

(I)-EVID-1SG marry-SBJV-2PL together

Meaning 1: 'I advise you to get married.'

[... 'Getting married can mean that you get to take advantage of less tax on your savings interest.']

Meaning 2: 'You must get married, that is my firm moral stance.'

Example ( $3 \mathrm{~b}$ ) shows that a szerint-expression, in addition to the probabilistic/ evidential-inferential meaning (1a) and the quotative one (3a), can also express some kind of judgment ( $3 \mathrm{~b}$ ). In this case the expression cannot indicate outer world evidence and it necessarily encodes a subjective opinion of the speaker, practically their decision on some evaluation. Imperative sentences can serve as a source of further uses of szerint-expressions; (3c) can be interpreted both as advice (Meaning 1) and as an expression of the speaker's firm moral stance (Meaning 2). ${ }^{5}$

We intend to account for all these phenomena and a few further properties of szerint-expressions - including their acceptability in different sentence types, illustrated in (4) - in the representationalist dynamic discourse- and mind-representation theory $\Re$ RALIS. Due to the formal theoretical framework, we can capture and represent the source of evidence and epistemic possibility compositionally.

(4) a. Ili szerint-em/? -ed /-e [ott volt] szép.

Ili EVID-1SG -2SG -3SG there be-PAST pretty

'I/youSG/he consider(s) Ili [to have been there] pretty.'

b. Ili "szerint-em/ -ed /-e [ott volt] szép?

Ili EVID-1SG -2SG -3SG there be-PAST pretty?

'Do(es) I/youSG/he consider Ili [to have been there] pretty?'

c. Szerint-em/?" -ed/ -e házasodjanak össze!

EVID-1SG -2SG -3SG marry-SBJV-3PL together

Meaning 1: ' $\mathrm{I} /$ YouSG/He advise(s) them to get married.'

Meaning 2: 'You must get married, that is my/your/his firm stance.'

\footnotetext{
${ }^{5}$ In order to present not only self-constructed sentences, (i) and (ii) are naturally occurring examples from the Hungarian National Corpus (Oravecz et al. 2014); special thanks to Nóra Kugler). Notice that (i) is used to give advice and (ii) expresses moral concerns:

(i) Anyácska szerint a ruha az idomokat csábosan sejtesse. (\#19055477) 'Mama says a dress should temptingly imply the curves of the body'.

(ii) Ancika néni szerint ne kelljen nekem minden, ami a másé, mert az már túlzás. (\#191322) 'Aunt Ancika thinks/says that I should't desire everything that belongs to others, be cause that pretty much crosses all lines.'
} 
The structure of the paper is as follows. After sketching the relevant elements of the $\Re$ eALIS toolbox in section 2, section 3 presents the formal description of the intensional profiles of the three major sentence types, which, as shown in (4), are potential hosts of different types of szerint-expression; their intensional profiles are discussed in Section 4. The paper concludes with a short summary and the take-home message that event and experiencing state as temporally concurrent, in spite of its Montagovian foundation (Dowty et al. 1981), aims at serving as a "cognitively viable linguistic representation" (Andor 2011: 1, 8-9), whose distinguished importance comes from the crucial role of the expression of evidentiality in making language "a basic means of achieving epistemic control and intersubjective alignment" (Langacker 2017:15).

\section{ReALIS toolbox in the description of sentence types and discourse markers}

In Montagovian formal semantics (Dowty et al. 1981), sentence-sized propositional contents should be constructed so that the resulting formulas can undergo truth evaluation in arbitrary possible worlds. From the viewpoint of ReALIS, the basic task of pragmatics can be reformulated as the designation of certain possible worlds on the basis of the linguistic form created by the speaker. ReALIS thus captures intensionality with possible-world labels (see Tables 1, 3, 4 in Section 3-4) instead of higher-order logical formulas, criticized by Searle (cf. Andor 2011: 8-9).

The ReALIS framework is to be regarded as the representationalist counterpart (Kamp et al. 2011) of Lauer's (2013) antirepresentationalist dynamic pragmatics, provided that the first steps of both models are aimed at deciding what truth values the declarative, interrogative and imperative conventions "expect" in the addresser's and the adressee's definite possible worlds. A formal dynamic pragmatics, in our conceptualization, can capture the linguistic phenomena traditionally described in such concepts as illocutionary act/effect and perlocutionary effect (e.g. Searle 1979) via designating the relevant subset of the basis of interpretation. In the possible world of the addresser's beliefs, for instance, the ideal truth values according to the three conventions are $+1,0$, and -1 , respectively. In a declaration, the conveyed proposition $e$ is thought to be true. In a question, the truth of $e$ is unknown. The one who performs an imperative sentence should think that $e$ (still) does not hold. It can also be truth-evaluated in a similar manner whether the addresser assumes the addressee to consider $e$ true, to long for its realization, or to be able to carry it out. This recursion can then be followed iteratively in order to consider possible worlds such as those which can be characterized by questions like this: what are the addresser's beliefs, desires and intentions concerning the addressee's beliefs, desires and intentions concerning them, 
i.e. the addressers themselves. ReALIS intends to explore not only the possible worlds evoked by the major sentence types but also those evoked by discourse markers. The description of intensional profiles of sentence types and discourse markers serves the purpose of revealing how to read each others' minds.

To represent the (finite) information which is at the interlocutors' disposal in any discursive situation, we use a finite structure we call worldlet. A wordlet is essentially a Kampian discourse representation unit but one of mental nature; it is assumed to be stored in the interlocutors' mind as part of their current information state. In the course of the description of both the conventionalized intensional profiles of the sentence types or the discourse markers and the interlocutors' underlying mental states, it is essential to account for the propositions in question as true, undecided, or false - in accordance with the collections of pieces of information that the certain worldlets consist of. Instead of the usual triplet of $\langle+1,0,-1\rangle$, however, we go as far as proposing an 11-degree scale of fifths in order to capture "certainty-uncertainty - and the attitudinal space in between" (see Cantarini et al. 2014). Falseness, then, will correspond to $-5 / 5$, while $-3 / 5$ refers to the evaluation "quite probably not hold," for instance. Instead of such fractions, however, we are going to use the set $\langle-5,-4$, $-3,-2,-1,0,+1,+2,+3,+4,+5\rangle$ of whole numbers. Truth and falseness will thus be expressed by the whole numbers -5 and +5 , respectively.

It is a hot topic in modern discourse-representation theories that a discourse referent is typically "in the crossfire" of several mental attitudes (Maier 2016: 477), which also holds for eventual referents (which refer to states of affairs, events, actions). That Katy kissed Alex, for instance, can be a sensorial experience for an accidental witness (E: experience), as well as a belief for her sister (B: belief, "it is likely that there was a kiss..."), which the sister, say, is glad about (D: desire). It might also be that kissing Alex appeared among Katy's plans at a certain moment (I: intention). Attitudes can also be embedded in each other recursively. Katy's plan, for instance, can be conjectured by her sister, placing the given eventual referent in a B-I type worldlet. Suppose further that their brother knows nothing about Katy's sister's conjecture: this way we have reached a B-B-I type worldlet.

The thesis of $\Re$ ReALIS is that conglomerates of such worldlets of complex indices are mobilized in interlocutors by discourse markers, after having set certain worldlet combinations as basic values via selecting the sentence type. In everyday communication these worldlets are more or less mutated partial mirror images of each other. From our Montagovian formal semantic departure, thus, we can arrive at the same questions as mind theorists, who conduct research into how and to what extent we attempt to see into each others' minds, that is, how we can mentalize each other (Wimmer and Perner 1983).

It is commonplace that language is a means for human beings to express their beliefs, desires, intentions, and to talk about several further objects of worlds hidden in their minds in numerous ways. What ReALIS aims at demonstrating 
in all related publications resting upon this approach is that, within this huge world structure, the substructures evoked by given linguistic items can be much more precisely and formally identified than many would think. What obscures this alleged concreteness for the researchers, then? The interlocutors' freedom to not only use but also misuse the worldlet-mobilizing potential of sentences, or at least, the ability of using this potential "creatively" or indirectly.

The system of worldlets that our approach is based upon relies on a structured set of labels. Attitudes such as belief (B), desire (D), and intention (I) are central components of the last decade's ReALIS-descriptions. This BDIlanguage has recently been completed with an attitude referred to as authority (A). As our beliefs, desires and other attitudes are in permanent change, a dynamic pragmasemantic theory should capture this temporal feature. It should also capture the property of communication that a person (say, in the dimension of B-attitude) considers different things to be true than another person does. In addition to the attitudinal component, thus, a worldlet label should also contain a temporal "stamp", as well as some reference to the host of the given worldlet.

As an illustration, let us consider the following three triplets: $\mathrm{iD0}, \mathrm{uB}+, \mathrm{oA}$. The first character in the sequences refers to the addresser ('I'), the addressee ('you'), and to someone who does not take part in the conversation under consideration ('other') respectively. The third character marks the point of time relative to the utterance time 0 as follows: ' + ' refers to a later point and '-' to a previous one. Thus, iD0 indicates the worldlet of "my present desires", uB+ that of "your later beliefs", and oA is the simplified indication of a third person's authority. These labels can be built on each other in unbounded recursion. The worldlet with the label $\mathrm{iBuBiB}$, for instance, is a distinguished one for mentalization: it is a collection of the addresser's beliefs concerning the addressee's beliefs about the addresser ("I believe that you believe that I belive..."). In other words, what is considered here is how "I assume to be viewed by you."

\section{Intensional profiles of major sentence types}

This section presents the intensional profiles of the major sentence types: declaratives, interrogatives and imperatives.

\subsection{What do we know, what do we long for, what do we have authority over, and on the basis of all this, what do we want from the listener?}

Our formally-defined intensional profiles are designed to capture how a proposition $e$ conveyed by a sentence is enveloped in possible worlds - or more precisely, in partial ones called worldlets - responsible for its illocutionary 
force. Truth evaluation in worldlets labeled $\mathrm{iB}, \mathrm{iD}$ and $\mathrm{iA}$, on the one hand, and $\mathrm{iBuB}, \mathrm{iBuD}$ and $\mathrm{iBuA}$, on the other, reveals what the ideal addresser, while performing a sentence with content $e$, believes, longs for, has authority over, and assumes the addressee to believe, long for, and have authority over. All this is then completed with the worldlet of intentions. In particular, the worldlet with label iIuI+ plays a crucial role: "[I intend you to intend $e$ ']" where $e$ ' is a propositional content to be judged on the basis of $e$, the content immediately conveyed by the given sentence.

The general conception sketched in the previous paragraph is presented in a formalized way in Table 1 as an underspecified intensional profile with the name 'target-oriented mentalization'. We attribute significance to such a fictive profile, which serves as the shared basis for the intensional profiles which define the three major sentence types, primarily in the process of constructing our comprehensive mental system of conventionalized intensional profiles. In the course of language acquisition infants obtain meagre data, at least compared to the high complexity of the system. Hence, we rest on the idea that the acquisition of the system requires that they often have recourse to general methods of creating lacking truth values in profiles such as compositionality (in the Fregean/Montagovian sense), opposition, and transferring values.

The profile of target-oriented mentalization describes a conscious being concentrating on a state-of-affairs $e$, whose $[-5,+5]$ scale in the iB-dimension is exactly distributed into three disjoint intervals by the three major sentence types. Value -5 provides profile for the speaker who, aware of the fact that e does not hold, intends to change that state of things, by calling the listener for help, using an imperative sentence. The situation in which $i B \in+5$ may stimulate readiness for cooperation: as information is valuable, supplying the listener with e which the speaker knows to be true, is likely to serve the listener's interest. The situation in which $i B \in[-4,+4]=$ " 0 " can be construed as follows: the speaker is not in a position to carry out the former two types of action, so their obvious aim can be to reach one of these states $(\mathrm{iB}+\epsilon+5$ or $\mathrm{iB}+\in-5)$; this can be initiated by taking the addresser role of a yes-or-no question. ${ }^{6}$

6 ' $\mathrm{n}$ ' and " $\mathrm{n}$ " denote a narrow and a broader interval around $\mathrm{n}$ in the following precise sense: the former symbol means a (bell-shaped) normal distribution over interval $[n-2, n+2]$ while the latter one a flatter normal distribution over interval $[n-4, n+4]$. Symbols ' $n$, " $n$, n' and n" denote the left/right half of the corresponding normal distributions. $\Theta$ marks the special set $\{-5,+5\}$, and res ${ }_{\mathrm{e}}$ refers to the result state of the event structure of $e$. 


\begin{tabular}{|c|c|c|c|}
\hline $\begin{array}{l}\text { TARGET-ORIENTED } \\
\text { MENTALIZATION }\end{array}$ & $\begin{array}{c}\text { Declarative } \\
\text { BASIC }\end{array}$ & $\begin{array}{l}\text { IMPERATIVE } \\
\text { BASIC }\end{array}$ & $\begin{array}{c}\text { INTERROGATIVE } \\
\text { BASIC }\end{array}$ \\
\hline For $e: \mathrm{iB}$ & $\mathrm{iB}=\mathbf{a} \in+5$ & $\mathrm{iB}=\boldsymbol{\gamma} \in-5$ & $\begin{array}{c}\mathrm{iBiB}=\gamma \cdot \Theta=-5 \cdot 5 \\
\rightarrow \mathrm{iB} \in=0 "\end{array}$ \\
\hline$\underline{\mathrm{iBuB} \in} \in=$ & $\mathrm{iBuB} \in \alpha^{*}=" 0^{\prime \prime}$ & $\mathrm{iBuB}=\gamma \in-5$ & $\begin{array}{c}\mathrm{iBuBiB}=\Theta=5 \\
\rightarrow \mathrm{iBuBiB} \in "+5 \bullet \bullet^{(\prime)}+5 \bullet " 0^{\prime \prime}\end{array}$ \\
\hline $\begin{array}{l}\text { For } e^{\prime}: \ldots \cdot \mathrm{W} \\
\mathrm{r} \in \mathrm{R} \subseteq\{\mathrm{i}, \mathrm{u}, \mathrm{o}\}\end{array}$ & $\mathrm{W}=\mathbf{u B}+$ & $\begin{array}{c}(\mathrm{W}=0 \mathrm{~B}+)^{-} \\
\text {Default: } \mathrm{e}^{\prime}=\text { res }_{\mathrm{e}}\end{array}$ & $\mathrm{W}=\mathrm{iB}+$ \\
\hline$\left(\sum \underline{\mathrm{i}} \cdot \underline{\mathrm{rD}}\right) /|5 \mathrm{R}| \in=+5$ & $\mathrm{iBrDuB}+\in \Theta=5$ & For e’: $\mathrm{iBrD}$ & $\mathrm{iBrDiB}+\in \Theta=5$ \\
\hline \multirow{2}{*}{$\mathrm{iBuA} \in "+5 \cdot "+5$} & \multirow{2}{*}{$\mathrm{iBuAuB}+=\beta \in \Theta$} & \multirow{2}{*}{ For e': iBuA } & $\mathrm{iBuAiB}+\in \Theta$ \\
\hline & & & Crucial: $\mathrm{iBuB}=\beta \in \Theta$ \\
\hline For $e^{\prime \prime}:$ iluI $+\in "+5 \bullet+5$ & iIuI $+u B+=\alpha$ & For e: iluI+ & $\mathrm{iIuI}+\mathrm{iB}+=\beta$ \\
\hline \multirow{2}{*}{ 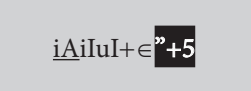 } & iAiluI $+u B+=\alpha$ & \multirow{2}{*}{ For e: iAiluI+ } & \multirow{2}{*}{$\mathrm{iAiIuI}+\mathrm{iB}+=\beta$} \\
\hline & Preferable: $\mathrm{iE}=\alpha$ & & \\
\hline
\end{tabular}

Table 1. The three basic conventionalized intensional profiles and their shared basis

The second step in the profile of target-oriented mentalization concerns the addressee. The question is what kind of knowledge (concerning $e$ ) renders the listener suitable for the addressee role. As we are now attempting to reveal the background of major sentence types which are not modified by discourse markers, the knowledge that belongs to the addressee role can be either the same as, or the opposite of, the knowledge of the addresser. More special relations should be marked (by discourse markers). The imperative will specify the background in the former way ("the same as"): it is on this - shared negative ( $\mathrm{iB}=\mathrm{iBuB}=-5)$ - basis that the speaker can call for a joining of forces in order to change the (unwanted) state of things. As for the latter way, what makes sense of uttering a declarative type is exactly the uninformedness of the listener: $\mathrm{iBuB} \neq+5$, with a speaker informed. ${ }^{7}$ A similar opposition makes sense of the interrogative type, except that now the listener is assumed to have the information: $\mathrm{iBuB} \in \pm 5$, with the speaker uninformed in respect of the truth value of e. Note that the informed status of $u$ can mean both knowing that $e$ is true, and that it is false. The $\mathrm{iB}$ component in label $\mathrm{iBuB}$ is responsible for mentalization ("What I think about you is that..."). The model we present in the table is that its value is " +5 (i.e., the left half of a bell-shaped distribution), in the case of worldlets $\mathrm{iBuD}$ and $\mathrm{iBuA}$, too. That is, the speaker's ideal position is to have sure knowledge about the listener's given attitude $(+5)$. The worst (still acceptable) case can be formulated as follows: it arises in the speaker's mind as a possibility $(\mathrm{iBuX}=+1)$ that the given attitude, $\mathrm{X}$ is what is prescribed in the given intensional profile as the value of $\mathrm{iBuX}$. This approach to mentalization

${ }^{7}$ The given value pertains to the underlined part of the complex label in question (but underlining can be omitted if the given n-tuple of values pertains to the last $\mathrm{n}$ worldlet components). If a pair or triplet belongs to a complex part of a label, the corresponding values are connected by the symbol ' $\bullet$ '. 
is very permissive and uniform; it expresses our experiences gained so far in the course of our research activity, lending no support to the idea that the speaker should monitor the attitudinal dimensions $\mathrm{uB}, \mathrm{uD}$ and $\mathrm{uA}$ differently.

The speaker thus concentrates his or her attention to an eventuality $e$ and assesses what he or she and his or her listeners know about the truth value of $e$ (szerint-expressions will increase this epistemic control over the given content. The next question, then, is what desire moves the speaker to the given speech act. It can generally be claimed that this desire pertains to an eventuality $e$ ' which has to be construed on the basis of $e$. Hence, in worldlets iD and $\mathrm{iBuD}$, it is $e^{\prime}$ that is there to be evaluated. As for authority, the listener has entire authority $(+5)$ over $e$ in an ideal case while in the worst case $(+1)$ they might be able to execute $e^{\prime}\left(\mathrm{iBuA} \in{ }^{\prime \prime}+5\right)$. In the case of an imperative, $e^{\prime}$ essentially coincides with $e$; only the truth value of $e$ should be reversed. As declaration and interrogation aim at transmitting some knowledge on $e, e$ s should be defined on the basis of output information states $\mathrm{uB}+$ and $\mathrm{iB}+$. If, for instance, $e$ is the state that Ili has moved back home (cf. (1a)), then $e$ is the event that [the corresponding interlocutor (I or you) learns that Ili has moved back home].

It has not yet been discussed which interlocutor's interest is to be served in the different major sentence types. The hypothesis we will argue for is that in the "discourse-markerless" basic case the decision is not made yet, but the speaker enforces some kind of mutual interest by using the major intensional profiles. In Table 1 the formula with summation is devoted to the formulation of this approach; subsection 3.2 will provide explanation.

The general formulation of addresser's intention should be related to a potentially third eventuality $e$ ", also to be calculated on the basis of $e$, whose achievement is assumed to require the addressee's aid (iIuI+: [I intend you to intend $e$ "]). In the imperative, the ultimate intention will pertain to the resetting of the truth value of $e$ in the external world, whilst declaratives and interrogatives serve the purpose of resetting the generalized truth value of $e$ in certain interlocutors' output information states.

Another generalization formulates when a speaker can take the addresser role of an intensional profile. Speakers are in a position to take this role if their intention to influence the partner does not violate any criterion of authority (iAiluI $+\in+5)$, or at least they think they have some argument for why they have authority (iAiluI $+=+1$ ).

To sum up, this subsection has attempted to capture what is common in the three major intensional profiles. There is a potential speaker concentrating on an eventuality $e$. He or she is speculating about $e$. What (s)he reaches will serve as a point of departure for something whose realization (s)he imagines to carry out with the aid of an addressee that (s)he selects and mentalizes. This process may halt at the level of a thought experiment, or get specified into the intensional profile of one of the major sentence types, resulting in the performance of a speech act. 


\subsection{Imperative profile}

As we strive for explanatory adequacy, we hypothesize that children - on the basis of the meagre data set available to them - possess the following system of intensional profiles. Only certain "generator values" should be set and kept in mind; they appear with a black background in Table 1. Other values in the profiles are decided by means of general constraints requiring certain values to equal or to stand in complementary distribution. The iBuB-values in the general target-oriented mentalization, for instance, are assumed to coincide with the iB-value or to be its opposite ( $\alpha^{*}$ is defined as the set consisting of the scale values which are not in set $\alpha$ or $\{\alpha\}$ ).

We attempt to base the current model of profile system on the assumption that the iB-value always serves as a generator, that is, "what I know about the truth status of the given eventuality" is a definitive point of departure for the intensional profile in question. The iB-generator of the imperative is the value -5 , as a truth value of the propositional content the given sentence conveys. The imperative in (5a), for instance, is senseless if Ili is (already) at home. The "negative knowledge" should be shared by both the addresser and the addressee: $\underline{\mathrm{B}}=-5=\mathrm{iB \textrm {BB }}$, as illustrated by the rejecting reaction of a potential listener presented in (5b).

(5) a. Ili, menj haza!
Ili, go-sBJv home
'Ili, go home!'

b. 'I am at home.'

Let us now turn to the dimension of desires and to the interests underlying them. Texts $(6 a-c)$ are all potential continuations at the speaker's disposal. The variants illustrate that, in the background of using the given imperative sentence (5a), there may stand the speaker's desire (6a) as well as the listener's one (6b), or perhaps that of an outsider (6c). Moreover, to carry out $e$ may be a mutual interest, at least in the speaker's opinion (6d). Accounting appropriately for all these facts requires a flexible model.

(6) a. I am fed up with you.

$\mathrm{R}=\{\mathrm{i}\}$

b. You had better go home.

$\mathrm{R}=\{\mathrm{u}\}$

c. Are you saying this because of my husband? He is watching a match right now with his friends, and he prefers if I don't disturb him at home.' $\mathrm{R}=\{\mathrm{o}\}$

d. (6a) $+[$ I'm convinced that this way both of us will feel better.] $\mathrm{R}=\{\mathrm{i}, \mathrm{u}\} ;(\underline{\mathrm{BBDD}} \cdot \mathrm{iBiD}+\underline{\mathrm{iBuD}} \cdot \mathrm{iBuD}) / 10=(5 \cdot 5+3 \cdot 4) / 10=3,7$

In an ideal model the desires considered should be averaged, or rather, summarized as a first step. It is also worth considering that the speaker is likely to 
be aware of others' desires in different degrees; it is the technique of weighting that the mathematical toolbox offers in such cases. The formula with summation in Table 1 can elegantly be called the epistemically weighted average of interests. There is a calculation associated with (6d) illustrating the formula. The subtotals emerge as follows. 5.5: the speaker is absolutely sure that they want the listener to leave; $3 \cdot 4$ : the speaker finds that the listener probably has a strong desire to go home. Then the sum of subtotals should be divided by two, i.e. by the number of those taken into account, as the speaker and the listener have been considered, and then also by five, as the scale of values rests upon fifths. The set $\mathrm{R}$ of those whose desire is taken into account, provided by the addresser profile proposed in an underspecified manner, serves as a key ingredient of the $\mathrm{D}$-dimension in all the three specified variants of target-oriented mentalization, but will not be discussed in 3.3 and 3.4. One might think that it offers too much freedom, but we claim that it will get specified just like pronouns such as this or everyone in real contexts. Speakers know whose interest they intend to serve, and listeners should also make a reliable decision on the given interests (6).

In the dimension of intentions (see Table 1), $e$ itself plays the role $e$ " in target-oriented mentalization ([I intend you to intend $e$ "]), or, within its complex event structure, its preparatory phase does. In the case of (5a), for instance, the listener is instructed (to begin) to go home. As for authorities, the speaker must have authority over warranting the issue while the listener must be able to perform it. Both parts may be refused, as shown in $(7 \mathrm{a}, \mathrm{b})$, in which the relevant components of the resisting listener's thoughts are presented in bold as reactions to the corresponding criteria concerning authorities.

(7) a. You are not in a position to give me commands.

iAiluI $+\rightarrow \mathbf{u B i A i I u I}+\in \mathbf{0}$

b. I am not able to go home this drunk.

$\mathrm{iBuA} \rightarrow \mathbf{u B u A} \in \mathbf{0}$

\subsection{Declarative profile}

Being in the possession of a piece of information ( $e$; see (8a)) - by this we mean the state $i B \in+5$ - what can the speaker want to gain from a listener? Obviously, something should be changed. This may be the alteration of the external world - by which we would return to the imperative sentence type, with the negative form "eventuality $e$ must not hold" (8a'). Or it may be the alteration of the listener's mind, the straightforward mode of which is to enrich the listener's information state with the fact that $e$ is true.

The prerequisite for this latter action is as follows: $\mathrm{uB} \neq+5$, since something must be changed. Or more precisely, what the speaker is responsible for is that they more or less think so, indeed: $\mathrm{B} B \mathrm{BB} \in$ " $+5 \bullet "{ }^{\prime} 0$ ". If the speaker thinks that the listener is also aware of the truth of $e$, an adequate discourse marker should indicate this in order to create the appropriate addresser's profile (8b). A good 
reason for doing so is to initiate negotiation of common knowledge in order to, say, base a proposal on it in the continuation of the conversation, as illustrated in $\left(8 b-b^{\prime}\right)$.

(8) a. Ili vegán.

Ili vegan

'Ili is vegan.'

a. Ili shouldn't go vegan. Vegan diets do not provide vitamin K2.

b. Szóval Ili vegán. / Ili tehát vegán.

word-INs Ili vegan / Ili thus vegan

'Ili can thus to be conlcuded to be vegan.' / 'Ergo Ili is vegan.'

b. So we should treat her in the Green Elephant vegan restaurant.

As can be seen in Table 1, there is a subtle difference in numerical characterization between intention and desire/interest. The interest in information transmission pertains to finding out the truth concerning $e$. The relevant value of $\beta=\mathrm{iBrDuB}+$ is thus the set $\Theta=\{-5,+5\}$ of the two truth values (referred to as \pm 5 in the table); the addressee's authority also pertains to the "possession of" this knowledge: $i B u A u B+\in \pm 5$ ("no secret to them"). What the addresser can intend to carry out, however, is to transmit his or her knowledge with $i \mathrm{~B}=+5$ as the value iIuI $+\underline{u B+}$; the question of addresser's authority pertains to this value: iAiluI $+\underline{u B}+=+5$. The two authority values are independent of each other, which can be exemplified as follows. A doctor's patient is entitled to the information concerning the illness: $\mathrm{iBuAuB}+=+5$. If, however, the doctor happens to speak to the patient on the phone, they are not in a position to discuss certain details: $i$ AiIuI $+u B+=0$. Also, Table 1 provides the following complement to this latter criterion: the speaker's authority ideally rests upon their bodily experience based on sense organs $(\mathrm{iE}=+5)$.

\subsection{Interrogative profile}

By using worldlet labels to characterize the declarative and the imperative profile, as given in Table 1, we are in a position to provide a compositional implementation of Searle's (1979: 69) idea: The basic interrogative type is nothing else but asking the addressee, by an imperative profile, to enrich their, the addresser's, information state with the truth value of an eventuality e by means of a declarative profile. All the formal details underlying the worldlet labels provided in Table 1 cannot be discussed, but we are going to overview the crucial points.

Remember that the point of departure for having recourse to the imperative profile is a shared "negative state", which can be specified in the given case as follows: $\mathrm{iB} \notin \pm 5$ and $\mathrm{iBuBiB} \notin \pm 5$. That is, it is considered that both interlocutors 
are aware of the addresser's "unknown status": ...iBE"0" (9a). The latter formula expresses that the addresser has no bias towards the would-be answer; otherwise, the adequate formula is as follows: ...iB $\epsilon^{\prime}+4(9 b)$.

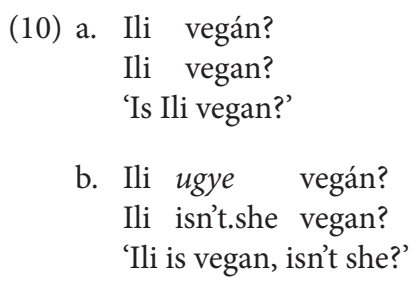

Some kind of desire or interest and the explicit intention of the addresser pertain to the appropriate modification of the "negative status": $\mathrm{iBrDiB}+\in \pm 5$, $\mathrm{iIuI}+\underline{\mathrm{B}}+\in \pm 5$, the addresser's output information state should already contain the truth value of $e$. The same motive of $\mathrm{iB}+\in \pm 5$ appears in the compositionally calculated authority formulas as well: $\mathrm{iAiIuI}+\mathrm{iB}+\in \pm 5$, "I am sure that I am in a position to ask this question," and $i \mathrm{BuAB}+\in \pm 5$. As for the latter formula, the crucial factor of the addressee's required authority is that they are in possession of the given piece of information: $\mathrm{iBuB} \in \pm 5$.

\section{Szerint-expressions in the three major sentence types}

This section is devoted to the characterization of the family of szerint-expressions. In Table 1 in section 3.1, an interesting asymmetry can be observed between the dimensions of beliefs and desires. In the B-dimension, only beliefs of the addresser and the addressee are considered relevant, i.e., values of $i B$ and $\mathrm{iBuB}$. In the $\mathrm{D}$-dimension, a third party's desire is also to be considered: a sum formula was based upon values of $\mathrm{iD}, \mathrm{iBuD}$ and $\mathrm{iBoD}$. The importance of szerint-expressions lies with elimination of this asymmetry, by making it possible to involve a third participant's (an Experiencer's) opinion in the discourse: the speech act may rest upon a simultaneous consideration of $\mathrm{iB}, \mathrm{iBuB}$ and $\mathrm{iBoB}$, see Tables 3-4. First of all, however, consider Table 2, in which the 18 szerintvariants ( 3 persons $\cdot 3$ sentence types $\cdot 2$ attitudes) presented in ( $4 a-c)$ in Section 1 , completed with the corresponding quotative variants and two discourse markers, szóval 'so (what can be concluded)' and viszont 'however', are classified according to a generalization of basically Langackerian inferential paths. ${ }^{8}$

8 "Language is a basic means of achieving epistemic control and intersubjective alignment. I view evidentiality as one dimension of epistemic assessment, which is best treated in a unified account of embodied experience and the striving for epistemic control. [...] The speaker - by following an inferential path - projects its realization with greater or lesser confidence" (Langacker 2017:15-21). 


\begin{tabular}{|c|c|c|c|c|}
\hline \multicolumn{2}{|c|}{$\begin{array}{l}\text { EVIDENCE } \rightarrow \\
\text { EXPERIENCER } \\
\downarrow \quad(\text { PERSON 6) }\end{array}$} & $\begin{array}{c}\delta \\
\text { EVALUATION/DEFINITION } \\
\hookrightarrow X \rightarrow \ldots\end{array}$ & $\begin{array}{c}\text { EXPERIENCED } \\
\text { QUOTATION } \\
0 \rightarrow \ldots / \ldots \rightarrow 0\end{array}$ & $\begin{array}{c}\text { INDIRECT } \\
\text { INFERENCE/ADVICE } \\
\mathrm{E} \rightarrow 0 \rightarrow \ldots / \ldots \rightarrow 0 \rightarrow \mathrm{E}\end{array}$ \\
\hline \multirow{3}{*}{1} & $\ldots \rightarrow 1 \rightarrow 2$. & Szerintem/ØIli szép..$\rightarrow 2$ & $\varnothing$ Ili ott volt..$\rightarrow 1 \rightarrow 2$ & Szerintem Ili ott volt. $\mathrm{e}_{\rightarrow 0 \rightarrow 1 \rightarrow 2}$ \\
\hline & $1 \rightarrow 2 \rightarrow \ldots !$ & $\begin{array}{c}\text { Szerintem } / \varnothing \text { házasodjanak } \\
\text { össze! } !_{1 \rightarrow 2 \rightarrow 0}\end{array}$ & $\begin{array}{c}\varnothing \text { Házasodjanak } \\
\text { össze! } !_{1 \rightarrow 2 \rightarrow 0}\end{array}$ & $\begin{array}{c}\text { Szerintem/ } \varnothing \text { házasodjanak } \\
\text { össze! } !_{1 \rightarrow 2 \rightarrow 0 \rightarrow e^{\prime}}\end{array}$ \\
\hline & $\ldots \rightarrow 2 \rightarrow 1$ ? & $-{ }_{1 \rightarrow 2 \rightarrow 1}$ & $-{ }_{0 \rightarrow 1 \rightarrow 2 \rightarrow 1}$ & $-_{e \rightarrow 0 \rightarrow 1 \rightarrow 2 \rightarrow 1}$ \\
\hline \multirow{3}{*}{2} & $\ldots \rightarrow 1 \rightarrow 2$. & $\begin{array}{l}\text { Szóval szerinted } \\
\text { Ili szép. } 2 \rightarrow 1 \rightarrow 2\end{array}$ & $\begin{array}{l}\text { Szóval szerinted viszont } \\
\text { Ili ott volt. } 0 \rightarrow 2 \rightarrow 1 \rightarrow 2\end{array}$ & $\begin{array}{l}\text { Szóval szerinted } \\
\text { Ili ott volt.e } \rightarrow 0 \rightarrow 2 \rightarrow 1 \rightarrow 2\end{array}$ \\
\hline & $1 \rightarrow 2 \rightarrow \ldots !$ & $\begin{array}{l}\text { Szóval szerinted házasod- } \\
\text { janak össze! } !_{2 \rightarrow 1 \rightarrow 2 \rightarrow 0}\end{array}$ & $-2 \rightarrow 1 \rightarrow 2 \rightarrow 0$ & $\begin{array}{l}\text { Szóval szerinted házasod- } \\
\text { janak össze! } !_{2 \rightarrow 1 \rightarrow 2 \rightarrow 0 \rightarrow e^{\prime}}\end{array}$ \\
\hline & $\ldots \rightarrow 2 \rightarrow 1$ ? & Szerinted/ØIli szép? ${ }_{2 \rightarrow 1}$ & $\varnothing$ Ili ott volt? $?_{0 \rightarrow 2 \rightarrow 1}$ & Szerinted Ili ott volt? $?_{e \rightarrow 0 \rightarrow 2 \rightarrow 1}$ \\
\hline \multirow{3}{*}{3} & $\ldots \rightarrow 1 \rightarrow 2$. & Szerinte Ili szép. $3 \rightarrow 1 \rightarrow 2$ & $\begin{array}{l}\text { Szerinte viszont } \\
\text { Ili ott volt. } 0 \rightarrow 3 \rightarrow 1 \rightarrow 2\end{array}$ & Szerinte Ili ott volt. ${ }_{e \rightarrow 0 \rightarrow 3 \rightarrow 1 \rightarrow 2}$ \\
\hline & $1 \rightarrow 2 \rightarrow \ldots !$ & $\begin{array}{l}\text { Szerinte házasodjanak } \\
\text { össze! } \\
3 \rightarrow 1 \rightarrow 2 \rightarrow 0\end{array}$ & $\begin{array}{l}\text { Szerinte viszont házasod- } \\
\text { janak össze! } !_{3 \rightarrow 1 \rightarrow 2 \rightarrow 0}\end{array}$ & $\begin{array}{l}\text { Szerinte házasodjanak } \\
\text { össze! } \\
{ }_{3 \rightarrow 1 \rightarrow 2 \rightarrow 0 \rightarrow e^{\prime}}\end{array}$ \\
\hline & $\ldots \rightarrow 2 \rightarrow 1$ ? & Szerinte Ili szép? $3 \rightarrow 2 \rightarrow 1$ & $\begin{array}{l}\text { Szóval szerinte viszont } \\
\text { Ili ott volt? } ?_{0 \rightarrow 3 \rightarrow 2 \rightarrow 1}\end{array}$ & Szerinte Ili ott volt? $e_{e \rightarrow 0 \rightarrow 3 \rightarrow 2 \rightarrow}$ \\
\hline
\end{tabular}

Table 2. The influence chain of szerint on the basis of the evidence of the recipient (sentences $(4 a)-(4 c))$

It is indicated in each cell how information travels from a piece of evidence to the interlocutor, who is assumed to require it in the given speech act. The interlocutor in question is the addressee in the case of declarations $(\ldots \rightarrow 2)$ and demands $(\ldots \rightarrow 2 \rightarrow \ldots)$, and the addresser in the case of questions $(\ldots \rightarrow 1)$. In the case of evaluation, each person can serve as the source of evidence $(X \rightarrow \ldots$, where $\mathrm{X}=1,2$, or 3 ). Otherwise, the evidence is in the outer world, referred to by 0 ; and e stands for the proposition the sentence with the given szerint-expression expresses, which does not coincide with the outer piece of experience in the evidential-inferential scenario. Three examples will serve as an illustration.

Chain $\mathrm{e} \rightarrow 0 \rightarrow 2 \rightarrow 1 \rightarrow 2$ means this: "I am conveying the information that Ili was there (e), witnessed by the fact that, say, you saw her coat hanging in the hall $(\ldots 0 \rightarrow 2 \ldots)$ and told me about it, and I am now reporting it back to you as a summary $(\ldots 1 \rightarrow 2 \ldots)$." As this reporting back to someone $(\ldots 2 \rightarrow 1 \rightarrow 2 \ldots)$ is strange, the corresponding type of sentence is higly marked (4b), but it can be repaired with the aid of the discourse markers presented in (8b), as shown in Table 2.

Let us now consider a short chain: $2 \rightarrow 1$. The outer world is irrelevant, "you yourself are the source of evidence $(2 \rightarrow \ldots)$, what counts is your evaluation; and the information should reach me $(\ldots \rightarrow 1)$," since a question is considered.

Finally, let us discuss chain $0 \rightarrow 1 \rightarrow 2$. "The outer world has sent me a message $(0 \rightarrow 1 \rightarrow \ldots)$, that is, I could experience something, which I am now telling you $(\ldots \rightarrow 1 \rightarrow 2)$." Table 1 shows that in the given case the insertion of the corresponding szerint-expression (szerintem 'according to me') is excluded, since it would (incorrectly) indicate indirect evidence $(e \rightarrow 0 \rightarrow 1 \rightarrow 2)$. Unmarkedness serves as an indication of the fact that the evidence comes indirectly from the addresser. 


\begin{tabular}{|c|c|c|c|}
\hline \multicolumn{2}{|c|}{ Declarative } & IMPERATIVE & YES/NO QUESTION \\
\hline Quotative szerint- $\delta$ & \multicolumn{3}{|c|}{ Probablistic szerint $-\delta$} \\
\hline \multirow[t]{2}{*}{$\begin{array}{c}\delta=0: \mathrm{iB} \delta \mathrm{B}=+5+5 y \\
\mathrm{iB} \in \text { "0" }\end{array}$} & $\begin{array}{c}\delta=0: i B \delta B=+5 \bullet^{\prime}+4 \gamma \\
i B \leq \gamma\end{array}$ & $\begin{array}{r}\delta=0: i B=-5 \\
i B \delta B \in+5 \bullet-5\end{array}$ & $i B \in$ "0"v \\
\hline & $\delta=1: \delta \mathrm{B} \in \in^{\prime}+4$ & $\delta=1: \delta \mathrm{B}=-5_{\gamma}$ & $i B \in$ "0" \\
\hline \multirow[t]{2}{*}{$\begin{array}{c}\delta=0: i E=0 \\
i E^{\prime}=+5 \\
i B \delta E \epsilon^{\prime}+5 \bullet^{\prime}+5\end{array}$} & $\begin{array}{c}\delta=0: \mathrm{iE}=0 \\
\mathrm{iE}=+5 \\
\mathrm{iB} \delta \mathrm{E}={ }^{\prime}+5 \bullet 0 \\
\mathrm{iB} \delta \mathrm{E}^{\prime}=+5 \bullet+5\end{array}$ & & $\begin{array}{c}\delta=0: i \mathrm{E}=0 \\
\mathrm{iB} \delta \mathrm{E} \in^{\prime}+5 \bullet 0 \\
\mathrm{iBuB} \delta \mathrm{E}^{\prime} \in^{\prime}+5 \bullet^{\prime}+5 \bullet+5\end{array}$ \\
\hline & $\begin{array}{c}\delta=\mathrm{i}: \mathrm{iE}=0 \\
\mathrm{iE} \mathrm{E}^{\prime}=+5\end{array}$ & & $\begin{array}{c}\delta=\mathrm{u}: \mathrm{iE}=0 \\
\mathrm{iB} \delta \mathrm{E} \epsilon^{\prime}+5 \bullet 0 \mathrm{iB} \delta \mathrm{E}^{\prime} \epsilon^{\prime}+5 \bullet+5\end{array}$ \\
\hline $\begin{array}{c}\mathrm{iBuB} \in \text { “0” } \\
\mathrm{iBuB} \delta \mathrm{B} \in \text { “"0"•+5 }\end{array}$ & $\begin{array}{c}\mathrm{iBuB} \leq \boldsymbol{\gamma} \\
\mathrm{iBuB} \delta \mathrm{B} \in \mathrm{u}^{\prime \prime} \cdot \boldsymbol{\gamma}\end{array}$ & $\mathrm{iBuB} \in "+5 \bullet \gamma$ & $\mathrm{iBuBiB} \in$ " +5 •(')+5 " 0 " \\
\hline \multicolumn{2}{|c|}{$\mathrm{W}=\mathrm{uB}+$} & Default: $e^{\prime} \neq$ res $_{e}$ & $\mathrm{~W}=\mathrm{iB}+$ \\
\hline \multicolumn{2}{|c|}{$\begin{array}{l}\text { (R) } i B r D u B+= \pm 5_{\beta} \text { or } \\
\text { (R') } i B r D u B+\delta B+=\boldsymbol{\gamma}\end{array}$} & For e': $\mathrm{iBuD}(\mathrm{R}=\{\mathrm{u}\})$ & $\begin{array}{l}\text { (R) } \mathrm{iBrDiB}+= \pm 5_{\mathrm{\beta}} \text { or } \\
\text { (R') } \mathrm{iBrDiB}+\delta \mathrm{B}+=+5\end{array}$ \\
\hline \multicolumn{2}{|c|}{$\mathrm{iBuAuB}+\delta \mathrm{B}+=\gamma$} & For e or res $e_{e}: \mathrm{iBuA}$ & $\begin{array}{l}\mathrm{iBuAiB}+\delta \mathrm{B}+=\gamma ; \text { Crucial: } \\
\mathrm{ABS}(\gamma) \leq \mathrm{ABS}\left({\left.\mathrm{iBuB} \delta \mathrm{B}_{\beta}\right)}\right)\end{array}$ \\
\hline \multicolumn{2}{|c|}{$\mathrm{iIuI}+\mathrm{uB}+\delta \mathrm{B}+=\gamma$} & For $e:$ iluI $+\in "+5 \cdot+4$ & $\mathrm{iIuI}+\mathrm{iB}+\delta \mathrm{B}=\beta$ \\
\hline \multicolumn{2}{|c|}{ iAiluI $+u B+\delta B+=\gamma$} & For $e$ : iAiIuI $+\in "+5 \bullet^{\prime}+5$ & $\mathrm{iAiluI}+\mathrm{iB}+\delta \mathrm{B}=\beta$ \\
\hline
\end{tabular}

Table 3. Well-formed quotative and probabilistic szerint-types in the three major sentence types (see (4))

Tables 3 and 4 present the entire contribution of szerint-expressions relative to the matrix intensional profiles given in Table 2, that is, the increment. The reader is encouraged to puzzle out the details; here only the crucial data are commented on.

$B$-dimension. Experiencer $\delta$, whose potential coincidence with "me" or "you" is treated as a special case, is always considered to have more reliable knowledge on the given e than others: $\mathrm{iB} \delta \mathrm{B}=+5$ in quotation and evaluation, and $\geq i \mathrm{~B}$ and $\mathrm{iBuB}$ in inference. This factor ensures the usefulness of the utterance in an essentially Gricean sense, besides the low values of $\mathrm{iBuB} \delta \mathrm{B}$, which ensures that "your output information state will contain more precise information". $\mathrm{B} B \mathrm{~B}=+5$ if the experiencer is quoted as the immediate source of some outer evidence (Table 3) or responsible for their own judgment (Table 4). The judgmentive character (see Table 4) is captured in ReALIS as follows: $\mathrm{iB} \delta \mathrm{B}=+5$ (e.g. "Ili is cute") and $\mathrm{iBrB}=-5$ ("Ili is ugly") are parallelly assumed, which is not the case if $e$ is a state of affairs whose truth can unambiguously be determined in the world.

$D$-dimension, I-dimension, A-dimension. The common label component in quotation, inference and evaluation is iluI+: "I intend you to get prepared for some change (you should want that), which is considered to be in the interest (D) of a group R or R' whose identity the addressee should figure out in successful communication and "authorized" for you and me (A)." The change pertains to "your output knowledge" $(\mathrm{uB}+)$ in declaration, and "mine" $(\mathrm{iB}+)$ in question, and is indirect modulo e (obtaining whose precise truth value is the ultimate target) but direct modulo worldlets $x \mathrm{~B}+\delta \mathrm{B}+$ (the experiencer's 
information concerning $e$ ). The imperative case is special if the (otherwise) probabistic szerint-expression is used. Instead of iluI $+=+5$ ("I want you to accept my instruction"; see Table 1), iluI+E'+4: "I can tolerate it if you do not entirely commit yourself to my instruction, which is factually an advice" (Table 3). The imperative is also special in the evaluative mode (Table 4): here the instruction is strong but the addresser should be aware of the fact that others may give an opposite instruction. ${ }^{9}$

E-dimension. It is primarily the value of $\mathrm{iB} \delta \mathrm{E}("+4 / 0 /$ undefined) that distinguishes the three types of pragmasemantic contribution of szerintexpressions. In the quotative, inferential, and evaluative cases, respectively, the given state of affairs is preferably directly experienced in the outer world by $\delta$ / not experienced / undefined. Symbols E' and E" in Tables 3-4 refer to experiencing attitudes about eventualities $e$, and $e$ ", which are related to $e$ in the interlocutors's mental networks indirectly / "more indirectly", in a way illustrated in Table 2. "Me knowing about the experiencer's indirect evidence ( $\left.\mathrm{iB} \delta \mathrm{E}^{\prime}=+5\right)$ ", for instance, is to be regarded as an even more indirect evidence "to $\mathrm{me}$ " $(\mathrm{iE}$ " $=+5)$, see Table 3 . In Table 4, the indirect evidence behind subjective evaluation $\left(\mathrm{iB} \delta \mathrm{E}^{\prime}=+5\right)$ is to be interpreted, say, in the case of Ili's cuteness as follows: "my judgment rests upon a conglomerate $e$ ' of her experienceable properties".

The last comment, together with a few earlier ones, suggests a seemingly attractive generalization on the interpretation of szerint-expressions in given contexts: according to the corresponding predicate being subjective or objective, the evaluative or the inferential interpretation is triggered, respectively, with a quotative interpretation also emerging in the latter case, although requiring special discourse markers (see the middle column in Table 2). The real picture is somewhat more complex. On the one hand, there are "essentially objective" predicates, which can, however, also be used "subjectively" - while interlocutors are contending over their definitions. The sentence in (1a), for instance, can be interpreted as follows: "what I can observe ( $\mathrm{iB} \delta \mathrm{E}^{\prime}=+5$ : say, Ili no longer sleeps where she used to but her furniture is still there) is enough for me to say that Ili has moved back home," while another person may insist on saying that Ili will only have moved back home if all her furniture is back there. On the other hand, "essentially subjective" predicates can also be used "objectively": if, for example, the speaker - instead of their own opinion - provides us with a summary of others' (potential) opinions.

\footnotetext{
${ }^{9}$ In Tables 2, 3 and 4 it can be observed that in ReALIS, imperative is treated as an inverted information flow: "I want you to carry $e$, which can metaphorically be regarded as informing the oracle of the outer world that $e$ is now true." Otherwise, the default starting-point of the information flow is the outer world.
} 


\begin{tabular}{|c|c|c|c|}
\hline \multicolumn{2}{|c|}{ Declarative $(\gamma=+5)$} & YES/NO QUESTION $(\gamma=\Theta, \mu="+5)$ & IMPERATIVE $(\gamma=-5)$ \\
\hline$\delta=0$ & $\mathrm{i}$ & $\mathrm{u}$ & o \\
\hline $\mathrm{iBoB}=\alpha \bullet \gamma, a, \gamma=+5$ & $\mathrm{iB}=\boldsymbol{\gamma}$ & \multirow{2}{*}{$i B \delta B \in " 0 " \cdot \gamma, \gamma \in \Theta= \pm 5$} & $i B=\gamma \in-5$ \\
\hline \multicolumn{2}{|c|}{$\mathrm{R}^{\mathrm{n} i \mathrm{BrB} \in-5}$} & & $\mathrm{iBoB}=+5 \bullet \gamma$ \\
\hline \multicolumn{3}{|c|}{$\mathrm{iE}$ undefined } & \\
\hline $\mathrm{iBoE}=+5 \bullet+5$ & $\mathrm{iE}=+5$ & $\mathrm{iB} \delta \mathrm{E}^{\prime}=+5 \bullet+5$ & \\
\hline \multicolumn{2}{|c|}{$\mathrm{iBuB} \delta \mathrm{B} \in \alpha^{*} \bullet \gamma\left(\alpha^{*}=“ 0^{\prime \prime}\right)$} & $\mathrm{iBuBiB} \delta \mathrm{B} \in "+5 \bullet+5 \bullet " 0 " \bullet \gamma$ & $\mathrm{iBuB}=\gamma \in-5$ \\
\hline \multicolumn{2}{|c|}{$\mathrm{R} \mathrm{iBrDuB}+\delta \mathrm{B}+=\gamma$} & ${ }_{\mathrm{R}} \mathrm{iBrDiB}+\delta \mathrm{B}+=\gamma$ & $\begin{array}{c}\mathrm{R}=\{\mathrm{u} u \mathrm{iD} \\
\text { Typically: } \mathrm{e}^{\prime} \neq \mathrm{res}_{\mathrm{e}}\end{array}$ \\
\hline \multirow{2}{*}{\multicolumn{2}{|c|}{$\mathrm{iBuAuB}+\delta \mathrm{B}+=\gamma$}} & $i \mathrm{BuAiB}+\delta \mathrm{B}+=\gamma$ & \multirow{2}{*}{$\begin{array}{c}\mathrm{iBuA} \in+5 \bullet+5 \\
(\mathrm{e} \text { vagy rese) }\end{array}$} \\
\hline & & $\mathrm{iBuBoB} \in \mu \bullet \mu \bullet \Theta \quad \mathrm{iBuB} \in+5 \bullet \Theta$ & \\
\hline \multirow{2}{*}{\multicolumn{2}{|c|}{$\mathrm{iIuI}+\mathrm{uB}+\delta \mathrm{B}+=\gamma$}} & \multirow{2}{*}{$\mathrm{iIuI}+\mathrm{iB}+\delta \mathrm{B}+=\gamma$} & iIuI $+\epsilon^{\prime}+5 \bullet+5\left(e ; \gamma^{\prime \prime}=\right.$ iIuI +$)$ \\
\hline & & & 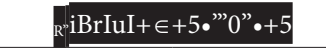 \\
\hline \multicolumn{2}{|c|}{$\mathrm{iAiIuI}+\mathrm{uB}+\delta \mathrm{B}+=\gamma$} & iAiluI $+\mathrm{iB}+\delta \mathrm{B}+=\gamma$ & iAiluI+= $\gamma^{\prime \prime}(\mathrm{e})$ \\
\hline
\end{tabular}

Table 4. Evaluative szerint-types in the three major sentence types (see (4))

\section{Conclusion}

Szerint-expressions associated with human participants are multifaceted: in addition to a probabilistic/evidential-inferential and a quotative meaning, they can also express some kind of judgment in declarative sentences and in questions. Imperative sentences can serve as a source for further uses of szerint-expressions: they can be interpreted both as advice and as an expression of the speaker's firm stance typically based on moral concerns. We accounted for the complex distribution of the various uses in respect of person, attitude and sentence type in the representationalist dynamic discourse- and mind-representation theory $\Re$ ReALIS. The analysis shed light on how the expressions under investigation make language a basic means of achieving epistemic control and intersubjective alignment. ${ }^{10}$

Finally, let us conclude the paper by pinpointing what sets our approach apart from others that also strive for the description of "epistemic control and intersubjective alignment" (and interlocutors' intentions, relative credence levels, and source-for-commitments roles): that is, purely cognitive approaches (e.g. Fauconnier 1994) and common-ground based (Stalnaker 2002) formal approaches (e.g. Gunlogson 2008; Farkas and Roelofsen 2017).

As discourse situations are modeled in ReALIS in a way that interlocutors are represented as each-other-building lifelong discourse representation

${ }^{10}$ Szerint-expressions can also be associated with non-human participants in Hungarian, see (3a). This paper did not discuss this type - which, as we hypothesize, does not constitute a uniform further type beyond those taken into consideration in Section 4, but which can be traced back to them by finding the human minds behind the given szerint-expressions containing reference to objects or abstract concepts. 
structures by the mathematical technique of simultaneous recursion (Alberti 2000), Maier's (2016:476) words on the scientific status of "cognitive DRT" precisely hold true for ReALIS: "What is often glossed over in such linguistic applications - even in many analyses of attitude ascriptions ... - is Kamp's (1981) original motivation of reconciling Fregean formal semantics (as championed at the time by Montague ... [Dowty et al. 1981]) with a traditional, Lockean cognitive theory of communication in terms of speakers' and hearers' mental states. To this end, Kamp in his original presentations actually describes DRSs as representations of the mental state of the hearer, rather than of the more abstract notion of a Stalnakerian [e.g. Stalnaker 2002] common ground. ${ }^{11}$ What sets this cognitive conception of DRT apart from purely cognitive theories like Fauconnier's (1994) Mental Spaces, is that the DRS language has a precise syntax and model-theoretic interpretation. Hence, in addition to its cognitive interpretation, a DRS also represents the actual truth conditions of a sentence or discourse. Linguists have since stripped DRT of its cognitive interpretation. But Kamp and a few others have kept it alive, even extending DRT to a fullblown representational theory of attitudes..."

\section{References}

Alberti Gábor (2000). Lifelong discourse representation structures. Gothenburg Papers in Computational Linguistics 00-5, 13-20.

Alberti Gábor, Kleiber Judit (2014). Discourse representation with a radically new ontology. In Olomouc Modern Language Series 4, Ludmila Veselovská and Markéta Janebová (eds.), 513-528. Olomouc: Palacký University.

Andor József (2011). Reflections on Speech Act Theory: An interview with John R. Searle. International Review of Pragmatics 3, 1-12.

Cantarini Sibilla, Abraham Werner, Leiss Elisabeth (eds.) (2014). Certainty - Uncertainty - and the Attitudinal Space in between. Amsterdam: Benjamins.

Dér Csilla (2016). A szerintem diskurzusjelölő szinkrón és diakrón vizsgálata [Synchronic and diachronic examination of the discourse marker szerint 'according to']. In Távlatok a Mai Magyar Alkalmazott Nyelvészetben [Perspectives in Today's Hungarian Applied Linguistics], Andrea Reményi, Csilla Sárdi, and Zsuzsa Tóth (eds.), 474-485. Budapest: Tinta Könyvkiadó.

\footnotetext{
${ }^{11} \Re$ ReALIS refrains from the Stalnakerian concept of a common ground due to its infinite basis, too (viz. some crucial definitions rest upon infinite sets of infinite possible worlds). Defining infinite sets by predicate notation (in order to collect "such-and-such possible worlds") is a problematic sort of set specification, see Partee et al. (1990: 7-8), who add that "the simplest way to avoid such paradoxes [problems with set specification] and still be able to define most sets of relevance to ordinary mathematics is to provide a rule for generating elements 'recursively' from a finite basis." In ReALIS, as hinted on above, representations of minds in communication are not infinite but only unboundedly huge sets defined by simultaneous recursion, the recursive steps of which are exactly such as those defined in Tables 1, 3 and 4 (hence, ReALIS does not need two independent mechanisms for defining steps and contexts of communication).
} 
Dowty David R., Wall Robert E., Peters Stanley (1981). Introduction to Montague Semantics. Dordrecht: Reidel.

É. Kiss Katalin (2002). The Syntax of Hungarian. Cambridge: CUP.

Farkas Donka, Roelofsen Floris (2017). Division of labor in the interpretation of declaratives and interrogatives. Journal of Semantics 34(2), 237-289.

Fauconnier Gilles (1994). Mental Spaces: Aspects of Meaning Construction in Natural Language. Cambridge: CUP.

Gunlogson Christine (2008). A question of commitment. Belgian Journal of Linguistics 22, 101-136.

Kamp Hans (1981). A theory of truth and semantic representation. In Formal Methods in the Study of Language, Jeroen Groenendijk, Theo Janssen, and Martin Stokhof (eds.), 277-322. Amsterdam: Mathematical Centre Tracts.

Kamp Hans, van Genabith Josef, Reyle Uwe (2011). Discourse Representation Theory. Handbook of Philosophical Logic 15, 125 -394. Berlin: Springer.

Kugler Nóra (2012). Az Evidencialitás Jelölői a Magyarban, különös tekintettel az Inferenciális Evidenciatípusra [Markers of Evidentiality in Hungarian with Special Reference to the Inferential Type of Evidence]. Budapest: ELTE BTK Mai Magyar Nyelvi Tanszék.

Langacker Ronald W. (2017). Evidentiality in Cognitive Grammar. In Evidentiality Revisited: Cognitive Grammar, Functional and Discourse-Pragmatic Perspectives, Juana Isabel Marín, Arrese, Gerda Haßler, and Marta Carretero (eds.), 13-56. Amsterdam: John Benjamins.

Lauer Sven (2013). Towards a Dynamic Pragmatics. Stanford, CA: Stanford University. $\mathrm{PhD}$ dissertation.

Maier Emar (2016): Attitudes and mental files in DRT. Review of Philosophy and Psychology 7, 473-490.

Oravecz Csaba, Váradi Tamás, Sass Bálint (2014). The Hungarian Gigaword Corpus. In Proceedings of LREC 2014.

Partee Barbara H., ter Meulen Alice, Wall Robert (1990). Mathematical Methods in Linguistics. Dordrecht: Kluwer.

Searle John R. (1979). Expression and Meaning: Studies in the Theory of Speech Acts. Cambridge: CUP.

Stalnaker Robert (2002). Common ground. Linguistics and Philosophy 25, 701-721.

Willett Thomas (1988). A cross-linguistic survey of the grammaticalization of evidentiality. Studies in Language 12, 51-97.

Wimmer Heinz, Perner Josef (1983). Beliefs about beliefs: Representation and constraining function of wrong beliefs in young children's understanding of deception. Cognition 13, 103-128.

Anna Szeteli, Mónika Dóla, Gábor Alberti

Department of Linguistics, University of Pécs

ReALIS Research Team for Theoretical, Computational and Cognitive Linguistics

Ifjúság u. 6

H7624 Pécs

Hungary

anna.szeteli(at)gmail.com

dola.monika(at)pte.hu

alberti.gabor(at)pte.hu [ORCID: 0000-0001-8907-0715] 